\title{
The Translatability of Some Expressions Used in Food Invitations in the Jordanian Society From Arabic Into English
}

\author{
Sukayna Abdel Kareem Ali \\ P.O. Box 11942, The University of Jordan, Amman, Jordan \\ Tel: 962-79-170-9905Ｅ-mail: ali_sukayna@yahoo.com
}

Received: June 10, 2019

Accepted: June 25, 2019

Published: August 26, 2019

doi:10.5296/ijl.v11i4.14905

URL: https://doi.org/10.5296/ijl.v11i4.14905

\begin{abstract}
It is the good translation that conveys the spirit and ideas of the original text in all honesty and accuracy and it is characterized by smoothness and clarity so that the reader does not feel the text as being transferred from another language. This study was conducted to demonstrate if it is possible to translate some expressions used in food invitations in the Jordanian society from Arabic into English and to explain the relationship between language and translation. It was based on the descriptive approach and reference to previous studies. It was concluded that there is difficulty in translating some of the terms used in food invitations and it was recommended by the study to conduct more research in this area.
\end{abstract}

Keywords: Translation, Food invitations, Expression in food invitations

\section{Introduction}

God created people with social instinct. They love to communicate with others, and the denial of communication may lead to the individual's psychological and physical suffering and sometimes to a total collapse. So the individual seeks to build social relations with people, whether by meetings, messages or social media.

As many countries celebrate the events and festivals that have a special status and that are sacred among the people and connected to the present and the future, there is no doubt that these events - whether cultural, scientific, educational or social - strengthen the links between people. Arabs in particular give great importance to these events and invite people to participate them their weddings, graduation, or celebrating the birth of a new baby by eating sweets and food to strengthen the links between them (Ministry of Education and Education, 2006). 


\section{Macrothink}

International Journal of Linguistics

ISSN 1948-5425

2019, Vol. 11, No. 4

If blood creates strong and first-class relationships among individuals, it is only "salt" or food that strengthens and develops relationships and reflects the perceptions and culture of a society. Food is more effective in moving from lowest to higher Social communication among people. (Al-Sheikh. W, 2016)

However, in the Arab world when people are invited to eat, strong words and expressions are used to reflect the eloquence of the language. For example, the one who invites welcomes his guests saying:

(ملألتم أهلا و وطنتم سهلا). [halaltum?ahlanwawata?tumsahlan]. This is a sign of showing great respect and warm welcoming to the guest using highly standard Arabic. On the other hand, the person invited to eat responds with highly loaded words, such as your house is permanent (بيتكم, عامر) [beitkomª:mir].

The speakers of Arabic language have a high ability to use words and expressions that are highly exaggerated and eloquent in such occasions more than the speakers of English do, which sometimes leads to a difference in meaning or emphasis. From this point, the importance of this study emerged as it was conducted to indicate whether it is possible to translate the expressions used before, during or after food invitations from Arabic into English, whether they are said by the one who invites or the one invited, using the correct meaning and form.

\section{The Study Problem and Questions}

Arabic language is completely different from English which is developed into Western Germanic language. Both languages differ from one another in customs, traditions, terms, as well as linguistic differences that do matter in translation such as those related to pronouns, punctuation, numbering, synonyms, and words choice. All these differences constitute a barrier and a problem for translation from Arabic to English.

Many people have problems translating some of the Arabic words into English since some dictionaries of English and machine translation cannot translate these words with the accuracy required, and the words used in food invitations are just an obvious example about this. The questions of this study are:

- What are the suggestions for a good translation regarding expressions used in food invitations?

- What are the most important challenges facing this translation?

- What is the relationship between language and translation?

- Is it possible to translate some expressions used in food invitations in the Jordanian society from Arabic into English? 


\section{The Objective of the Study}

People communicate with each other through particular languages that enable them to understand each other. The language of communication varies among people depending on the place, the means and the reason of communication. This study was limited to the expressions used by members of the Jordanian society in food invitations, and it tried to:

1. Identify the most important suggestions for a good translation.

2. Identify the most important challenges facing translation.

3. Identify the relationship between language and translation.

4. Identify the translatability of some expressions used in food invitations in the Jordanian society from Arabic into English.

\section{Suggestions for a Good Translation}

One of the oldest bridges found among people is translation. Translation is one of the oldest human skills on which several civilizations were based. Acceptable translation covers or conveys the meaning of the original text to the text in the target language. The translation is good according to the evaluation of the transfer of meaning.

The translator must be fully versed in both languages. Translation has basic quality principles that can control the quality and professionalism of translation. There are many good suggestions by a good translator to overcome translation problems and get a good translation such as: (Sheikh.sh, 2014)

-Using the most general words and moving away from the individual words because translating a word alone and in its own sense may lead to a difference in meaning.

- Using the so-called cultural substitute which gives the reader the ability to comprehensively understand because it deals with common concepts.

-Using the paraphrasing technique because it provides a high level of accuracy and correct translation. The translator sometimes needs to rephrase some secondary sentences to illustrate the overall meaning of the sentences.

-Using omission if the word is redundant or repeated in the text

- Using loan words as the translator writes these words between quotation marks.

\section{The Difficulties When Translating From Arabic Into English}

Translation is a career that faces many challenges, including professional ones. Translators who understand the required language differences are trained when translating and know that there is no room for error (Aldossary, H., 2000). However, the challenges remain in this profession. The issue of cultural expressions, verses of the Koran, poetic proverbs, names of places and plants... etc. has special treatment when translated from Arabic to English, so the translator must understand the meaning of the text and message before starting the process of 
translation and must have the knowledge of the target culture because there are differences in cultures among peoples. (Bahameed, A, 2008)

The Arabic language is affected by a desert environment characterized by high temperatures and drought, unlike the English language, which develops into an environment characterized by low temperatures and humidity. Therefore, one must consider the changes in the weather to show the meaning of some words such as:

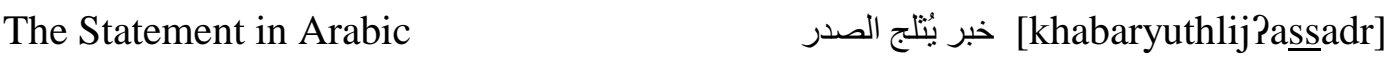

The meaning in Arabic [News] [Freezes] [The chest]

The translation in English What great news?

Or

This news is heartening.

Here in this example, the coldness was associated with happiness in accordance with the Arabic language environment, which may be misunderstood in English where it is interpreted as referring to good news. All these expressions are related to the language they belong to. There are expressions that cannot be translated from English into Arabic or vice versa.

There is also a difficulty in translating the proverbs according to the environment or culture prevailing in them, so that the translation of some proverbs becomes achievable and taken as a complete sentence, not every word alone, as in the following example:

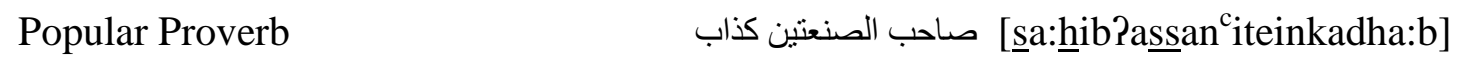

The meaning

[A companion of] [two professions] [is a liar]

The translation in English

A Jack-Of-All-Trades is a master of none.

It is clear from the above examples that the process of literal translation of many words is not permissible, so it is necessary to understand the sentence, the environment and the culture of the language to be translated.

\section{The Relation Between Languages and Translation}

The structure of the Arabic language and its syntax are different from English, and the effect of translation is penetrating into the depths of the language, making us feel that some texts written in Arabic are originally translated by a weak translator. (Assfor, M, 2007)

The Arabic language is different in its meanings from English. Many words have different meanings from their literal one. 


\section{Al Macrothink}

International Journal of Linguistics

ISSN 1948-5425

2019, Vol. 11, No. 4

Emotions and feelings that are translated may contain several meanings, including the meaning of a dictionary that is the literal translation of the word or the semantic meaning that is the conceptual expression of emotion, expressions and feelings. Emotional expressions evoke strong emotions such as sadness, joy, love and hatred. (Volek, B, 1987)

Translation can be defined as converting a text from one language into another while retaining the content of the message and features in the original text and preserving its meanings and references. This depends on the nature of the language and culture, and the translation cannot be considered as the transfer of meanings and words from one language to another because it includes a wide range of knowledge, experiences, customs and traditions obtained from society.

The translation has two main components: culture, language. The culture is the implicit things which refer to the beliefs and values that exist in a country and the language is the one that provides the people with the tools necessary to realize their culture. Each language group has its own culture. Sometimes the translator needs to understand and translate some hidden elements that are possible. The question of translation depends primarily on the translators because they understand the language and culture of the target language. They sometimes resort to the translation of words with synonymous close ones to perform the same function. They should have a good background on cultures so that they can compensate lost words with appropriate ones. Translators mediate between the original language text and the target text, so the translation process is entirely dependent on their skills and ability to provide the language text in a clear and readable manner. (Mahasneh, A., 2016)

\section{Expression in Food Invitation and Translation}

Inviting people is one of the repetitive functions that are answered with acceptance or rejection using daily terms colloquial and standard languages. These invitations are also made to maintain good relations with people (AlKhatib, M., 2006).

People are invited to participate in the celebrations, events and ceremonies by eating food. The following are examples taken from conversations among members of the Jordanian society regarding food invitations

\section{Example 1:}

Person A: دعانا أحمد التناول العشاء غدا و نود ان تكون معنا فما رأيك؟

$\mathrm{da}^{\mathrm{c}}$ a:na: Pahmadlitana:wulPal ${ }^{\mathrm{c}}$ asha:Pghadanwanawaddu Pantaku:nama ${ }^{\mathrm{c}}$ ana:]

(Ahmed invited us to a dinner tomorrow and we would love you to join us. So what do you think?)

Person B: انه من دو اعي سروري رح احضر إن شاء الله غدا

Pinnahu min dawa: ${ }^{c} \mathrm{i}$ : suru:ri: rahahahdarPinsha:PaPallahghadan

(It is my pleasure and I will hopefully come tomorrow) 
It is noticeable in the Arabic language that the first person made food invitation to eat dinner to the second person in the form of suggestion and not in a direct way. This is normal because Arabs belong to an indirect culture that is also known as high -context culture, unlike the westerners where direct cultures prevail. Moreover, Person A invited B although originally it is Ahmad's invitation not his, but again it is part of the Arabic culture to do that if person A has strong relations with Ahmad.

It is noted that person B responded by using "inshallah "which is only used in the Arab culture because it is part of Islamic expressions. It was translated as "hopefully" which is the closest in meaning in English.

\section{Example 2:}

Person A: بتشرفونا بكرا الساعة 5 لتناول طعام الغذاء

[bitsharfu:na: bukra: litanawulta ${ }^{\mathrm{c}} \mathrm{a}: \mathrm{m}$ ?alghadha?]

(We will be honored by your attendance tomorrow at $5 \mathrm{pm}$ for lunch.)

Person B: أنا بتشرف فيكم أكثر رح نكون موجودين بكر ا ان شاء اله

?ana: batsharaffi:kum ?akthar rah nku:nmawjudi:n ?inshallah

(I am more honored by you, I will be hopefully there)

The first speaker invited the second to lunch for tomorrow by complimenting him, saying that it is an honor for him if Person B accepted the invitation. B, in turn, responded positively saying that he is the one honored by the invitation and confirming that he is coming by using "inshallah.

\section{Example 3:}

زوّد :

(eat more)

Person B: يخلف عليكم و كثر الله خيركم

yikhlif ${ }^{\mathrm{c}}$ alaikum w kaththharallahkhairkum

May Allah grant you more)

It is just expected if you are invited by someone who belongs to the Arab culture to be told every now and then to eat and drink more. It is because Arabs consider it as a sign of generosity; the more you ask your guest to eat and drink, the more generous you are considered. This can be accompanied sometimes with expressions related to religion, such as (If you like Allah eat more), or (for the sake of Prophet Mohammad eat more).

B responded with a cultural -specific expression that has no direct equivalent in English and that is why it was translated literally as may Allah grant you more. Actually, the expression [yikhlif ${ }^{c}$ alaikum w kaththharallahkhairkum] consists of two parts that 
almost give the same meaning. The meaning is just repeated for emphasizing the idea of thanking the host person.

\section{Example 4:}

Person A: بانتظاركم غدا و الأعذار مرفوضة

bintiTha:rkumghadanwaPalPa ${ }^{c}$ dha:rmarfu:dah

(Waiting for you tomorrow and excuses are rejected)

Person B: الا تظلبو ا حالكم

la: tghalbu: halkum

To show that you are very serious about your invitation, it is normal in the Jordanian society not to give the other person the chance to think about accepting or refusing your invitations by using expressions like: excuses are rejected, we usually have lunch at $2 \mathrm{pm}$ so do not be late, or even by putting it in the form of a joke as in: no one dares to reject my invitation.

Person B responded by an expression which is difficult to translate by those who are not familiar with the Arab culture. Saying (لا تغلبو الكم) [la: tghalbu: halkum] in this context indicates that person B accepts the invitation but he is asking person A not to spend too much money on the invitation and not to make many different types of dishes.

\section{Conclusion}

It is noteworthy that translation from one language to another has played a great role throughout history. We see its current role in developing countries and benefiting from the achievements of others. We conclude from the study that Arabic is more eloquent and powerful in the expressions used to invite someone for food, and the study recommends conducting more researches and studies in this regard in the future.

\section{References}

Aldossary, H. (2000). The Difficulties Arising When Translating From Arabic To English.

Al-Khatib, Mahmoud. (2006). The pragmatics of Invitation Making and Acceptance in Jordanian Society. Journal of Language and Linguistics, 5(2), 272-294.

Al-Khawaldeh, A. (2018). Uses of the Discourse Marker Wallahi in Jordanian Spoken Arabic: A Pragma Discourse Perspective. International Journal of Humanities and Social Science, $8(6)$.

Al-Sheikh, W. (2016). Food and its role in establishing social relations. Palestinian Newspaper.

Assfor, M. (2007). The Effect of Translation on Arabic Language. University of Sharjah University of Shari'a and Humanities Sciences, 4(2).

Bahameed, A. S. (2008). Cultural Hindrances in Arabic-English Translation. Translation Journal, 12(1). 


\section{Macrothink}

International Journal of Linguistics

ISSN 1948-5425 2019, Vol. 11, No. 4

Mahasneh, A. (2016). Arabic Language and Emotiveness's Translation. International Journal of Social Science and Humanity, 6(4). https://doi.org/10.7763/IJSSH.2016.V6.65

Ministry of Education and Education. (2006). Directory of events, activities and celebrations. General Directorate of Educational Programs, Sultanate of Oman.

Sheikh, sh. (2014). The Importance of Cultural Awareness in English - Arabic Translation. Arab World English Journal.

Volek, B. (1987). Emotive Signs in Language and Semantics Functioning of Derived Nouns in Russian. Benjamin's Publishing, Amsterdam/Philadelphia.

\section{Copyrights}

Copyright for this article is retained by the author(s), with first publication rights granted to the journal.

This is an open-access article distributed under the terms and conditions of the Creative Commons Attribution license (http://creativecommons.org/licenses/by/4.0/) 